\title{
La doble voz
}

\section{The double voice}

(C) UNAN-Managua

Recibido: 24 de febrero 2021

Aprobado: 24 de marzo 2021
Jesús Miguel Delgado Del Águila

Universidad Nacional Mayor de San Marcos, Perú

tarmangani2088@outlook.com

https://orcid.org/0000-0002-2633-8101

\section{(c) (i) (9)}

Aunque sea por estar en la casa de Dios, que a la bestia no se le ocurra hacerme daño. Acaba de verme. Lo sé. Él tiene a su lado a su esposa, quien es también mi amante. Ambos caminan con precipitación: el horrendo monstruo tomándola con fuerza del brazo y agilizándola con el paso. La mujer está sudorosa. Parece que en cualquier momento va a estallar en llanto. Su cara pálida y sus gestos repulsivos la ayudan a verla como víctima. Todo el plan falló. Ni uno de los dos supusimos que el esposo nos seguía. Qué espantoso fue cuando pude reconocerlo a distancia. Ya ni fuerzas pensé que tendría para huir. Con rapidez, pude introducirme en esta gran iglesia de La Inmaculada; en cambio, nuestra mujer no pudo salirse con la suya: el señor bigotudo la agarró en plena desesperación y con insultos la dominó.

Procuro esconderme bien: cuando ellos desde el otro extremo están avanzando, yo retrocedo y me oculto detrás de los muros o el confesionario. Hay demasiada gente. Eso está a mi favor; sin embargo, este señor no desiste.

- Hazme tuya otra vez, Luciano. Tómame por donde quieras, que esta noche sea distinta de las otras. Impresióname, por favor.

- ¿Está bien así?

_iOh... sí! Cómo quisiera que este momento no acabase nunca. - Te veo enloquecer como una salvaje. Yo solo aprovecho las circunstancias: te beso con pasión. Dejo que mis labios reposen largamente sobre tu espalda, tu cuello, tus pechos... Te toco suavemente con la punta de mis dedos. Acaricio tu piel. Trato de que cada forma de expresión perdure por largo tiempo en tu ser. Qué hermosa eres: tus párpados semicaídos me excitan, tus labios también, tu piel blanca, tu cabello castaño, tus ojos claros, tus curvas, el brillo de tu cuerpo, el airecito que exhalas por tu boca... iCarambas! No encuentro ni una imperfección en ti, encima me amas... Cómo es posible que la vida me haya premiado de esa manera, sin yo ni siquiera merecerlo. Me detengo un rato. He perdido la noción del tiempo. Llevo largos minutos contemplándote, sintiéndote y halagándote. Y así me siento feliz. Ahora, es tu turno, sin ni siquiera yo decirte nada. Tal vez, tú me encuentres bello, como yo a ti, porque me besas con desesperación, te tiras encima de mí y me vuelves a llenar de besos por todo el rostro. Te quiero hacer el amor, pero tú aún no me dejas, conduces mis sádicas manos de tu cintura a mi pecho. Las oprimes con fuerza. Ya no me dejas hacer nada. Me he convertido en tu esclavo-. Luciano, cada vez que te vas, entristezco. ¿Qué puedo hacer para dejar de sufrir?

-Solo ámame.

— ¿Eso nada más? 
—Yo también sufro cuando nos separamos, pero no puedo hacer nada por solucionar ese problema.

- ¿Tú me ves como un problema?

-Claro que no, sino que... Espera, no te me pongas así. Tú sabes que te amo, pero por ahora no se me ocurre nada tan extraordinario como para estar más tiempo juntos.

-Me has dicho un problema.

- Te vuelvo a decir que no.

- ¿Tú me quieres?

-Te amo, Susana.

—Bésame, Luciano... Ay... Me haces cosquillas cuando me besas el cuello... Pero... me gusta... Y más me gustas tú... - Te entregas muy rápido a mí, mujer, pareciera como si yo tuviese las palabras y las acciones precisas para seducirte a mi manera y lograr lo que quiero. Cuántas veces ya te he hecho el amor. Casi ni las cuento. Cada vez es distinto y más apasionado. Mis mentiras fluyen como si estuviesen siendo dictadas por mi Padre que me ama, así como soy. Temo que, de tanto haber fingido algo, esté atrapándome. Me estoy enamorando de esta mujer, pues de tantas chicas que conozco y con las cuales podría estar, justo ella me está enamorando a diario.

Tuve que motivarme. No tenía escapatoria. Sé que en este preciso instante está mal que evoque a mi amada en su mejor naturaleza. Pero, para no quedarme tan tenso por lo que pasa ahora, me es indispensable recordar estas escenas bellas. Observo el desarrollo de la misa: el sacerdote está bendiciendo el cáliz, muchas personas están paradas golpeándose el pecho, otras arrodilladas con las manos juntas, otras conversando por celular, otras durmiendo, otras caminando, otras... ¿Dónde están ellos? ¿Ya se fueron? Por el momento, será oportuno salir de este confesionario vacío. Creo que la zona ya está más despejada, aunque no me puedo confiar demasiado. Salgo, camino por el pasillo que está rodeado de velas, arañas luminosas, estatuas y pinturas religiosas. Me pierdo por el gentío que está en las bancas, me arrodillo y trato de ocultar el rostro.

_iLuciano! iLuciano! —Esa voz se me hacía familiar, aunque proviniera de la calle. Acerté: era mi hermano, el más pequeño de todos. Parecía que tenía que darme una gran sorpresa, pues la expresión de su rostro era irradiante y me alegraba —. Tienes un encargo, picarón. Mira lo que te trajo una tal... Mmm, no sé, no dice su nombre, pero mira, es de una admiradora tuya, tal vez una de tus enamoradas. Aunque con ese regalo diría que es tu futura esposa... - Mi hermano se fue entre risas y me dejó un sobre... Un sobre abierto todavía.

“Luciano, discúlpame por no haberte afrontado. Tengo problemas acá en casa. Solo quería decirte que te quería mucho y que no te olvides de mí en ni un momento. Hoy es una fecha especial: cumplimos dos meses, mi amor. Tú sabes que yo las cosas me las tomo en serio; tratándose de una relación, aún más. Quería que este día no te lo olvidases jamás, tenme presente a donde vayas, siéntete feliz conmigo, sabiendo que no te puedo dar todo mi tiempo, tú sabes por qué. En recompensa, anhelaba dejarte un regalo que te fuera útil. Sé que le sacarás provecho. A mí, me costó mucho poder conseguir uno así: el tener que comprarlo a ocultas y el saber en qué instante hacerlo. Aquí está tu regalo pues, es todo mi amor, mi compañía, mi felicidad (no vayas a pensar que estos sentimientos son el regalo, sino que eso vale para mí lo que te estoy obsequiando). Mira el auto que he colocado al frente de tu casa. Hay un chofer adentro. Él te dirá todo lo que no sepas sobre ese modelo. Cuídalo bien y alégrate, porque el día que deje de pensar en ti ya habrá acabado mi existencia".

Esta mujer es obsesiva o quiere hacerme una emboscada. Yo apenas la conozco poco tiempo como para que me regale semejante obsequio. Eso yo no se lo puedo permitir... ¿Qué voy a hacer con ese carro? No sé manejar. ¿Dónde lo voy a guardar? No tengo cochera. Estoy asustado, ¿en qué me he metido? Sé que esta relación es peligrosa. Una mujer casada, de mucho dinero, con un esposo empresario y una casa lujosa. ¿Me estarán es- 
piando? ¿Qué querrán de mí? Esto no me gusta... ¿Y si esto es una emboscada? ¿Si la carta no la ha escrito ella? ¿Si el chofer es un encargado del mismo esposo de mi amada? iQué hago! Ese carro está llamando la atención de los vecinos. Hay muchas cabezas que se aproximan a la ventana y lo señalan. Mi hermano ya fue con el chisme. Escucho que mi familia baja por las escaleras para ver qué sucede. Nadie más que yo conoce a esa mujer. Me asusto...

—Demos gracias al Señor, nuestro Dios.

-Es justo y necesario.

Mi papá me está viendo. Su expresión es de temor, como si quisiera decirme: “¿En qué te has metido? Preferiste vivir libertinamente que pasarla con tu familia. Mira ahora...". Al verlo, tuve unos deseos de llorar. Nunca seguí sus consejos. Quise buscar mi vida como yo la quería. Pensé que la pobreza me arrastraría al seguir sus pasos, pues los dos teníamos dos senderos distintos. Su mirada me hizo rebajar mi actitud. Me hundió. Me hizo aterrizar de las nubes. Hizo sentirme hijo y no hombre. Llegaba mi mamá. Su aspecto demacrado y sufriente me hizo entrar en mayor remordimiento. Sentía como si ella se comunicara conmigo sin necesidad de abrir los labios, como si claramente ella me dijera: "Nunca me ayudaste en nada. Te dimos de todo y tú ni siquiera supiste aprovechar". Mis ojos se pusieron rojos. Se llenaron de lágrimas que no querían resbalar por mis mejillas. Me aguanté y me aguanto. No, esto no puede pasarme a mí. No puede ser posible. Todos me están mirando, a expensas de que me dirija a mi vehículo, pero... no puedo. Me dan ganas de mandar todo al maldito olvido. No puedo contenerme más: cojo la carta y la destrozo en pedazos. No soy yo el destinatario. Jamás he conocido a esa mujer. Ese carro de quién será. Ah, ¿dice mi nombre?, pues yo no me llamo así. Trato de ocultar mis sentimientos y me escondo. Mi familia se queda afuera a esperar qué sucede. Todo el vecindario está también a la expectativa. El chofer ya sabe que el auto es para mí y por eso no deja de desviarme la mirada. "Ya pues, hijito, acepta las condiciones y recoge el carro-", me habrá querido decir. Al ver que todo seguía estático, decidí partir, ¿a dónde? A donde sea.

—La paz del Señor esté con vosotros.

-Y con tu espíritu.

-Podemos darnos el saludo santo de la paz.

Corrí con desesperación. El cansancio y la adrenalina no me vencían. Yo era el supremo. Varias calles pasaron por mí. Sin percatarme, ya me encontraba algo lejano de casa, sin darme cuenta... Recordaba, recuerdo, recordé... Maldito tiempo... Cómo es posible que una mujer casada se tuviese que haber enamorado de mí. Yo apenas la quiero un poco, pero no tanto como para poder aceptarle un regalo de dudosa procedencia. Además, a mí solo me importa tener sexo con ella, lo demás es en vano. No me imagino pasar mi vida dependiendo de otras personas... No me imagino... La llamaré y terminaré con todo de una vez.

-Aló.

—¿Luciano, eres tú?

— iClaro que soy yo! Solo te llamaba para decirte que esto se acabó, ¿entiendes? Se acabó... No confío en ti, ni en nada de lo que me dices. El auto que me regalaste te lo puedes guardar... Yo no lo necesito, y menos te necesito a ti. Tal vez tu esposo te ame de verdad, porque yo en realidad no siento ni un poquito de amor por una mujer casada que en estas condiciones se asemeja más a una chica cualquiera... No me vuelvas a llamar en toda tu vida. Olvídate de mí para siempre... iPara siempre!

Creo que si hablara de esa forma me costaría la vida. Mejor será hacerlo personalmente. Regresaré a casa y le diré que se lo regrese a su dueña. Le diré que no me siento apto como para recibir algo tan preciado, pero que 
de todas maneras le agradezco el gesto. Nada más. Creo que así terminará bien. Yo a esa mujer la admiro por todo, no sería conveniente terminar con ella, porque aún siento que puedo aprovechar muchas cosas más de su persona. Nadie se percatará. Seré más precavido que antes, más astuto. Estos errores jamás volverán a ocurrir, jamás.

—Luciano, déjame que te siga besando, por favor, no te resistas. Hazme el amor otra vez... ¿Sí?

- Llevamos horas acostados y no me siento mal. Me gusta estar contigo. Me siento feliz que me hayas escogido como tu amante. Eres realmente hermosa, pero a la vez muy ingenua...

-Todo lo que hago es por amor, por amor a ti, querido.

—Lo sé. A veces, pienso cómo te tengo ahora y luego ya no. Quisiera que al hacerte el amor tú te quedaras conmigo para siempre o absorber algo de ti, si es posible toda tu belleza. ¿No te imaginas? Tener tu cuerpo para mí, tu belleza para mí, tu nombre y tu forma solo para mí...

-Estás bien loco, mi amor, pero si eso quieres yo haré todo lo posible por satisfacerte... ¿Por dónde quieres empezar? Ay, no me toques ahí... Ay, amor, ay... Me derrito, no puedo más, hazme tuya, ituya!...

—iHijo de puta, ya te agarré! —Esa voz no estaba en mis pensamientos—. iHijo de puta, sal de ahí! Tenía la cabeza gacha, escondida entre mis manos. Sentí que despertaba de mis recuerdos concomitantes: el alboroto, el jaloneo, los codazos y el murmullo asustadizo de la gente que tenía alrededor me hicieron entrar de nuevo en la realidad. Sin saber qué hacer, volteé la mirada para ambos lados. Lo que más me aterró fue percatarme de un señor de cabello y bigotes negros que se ponía colorado de cólera. Me miraba fijamente a los ojos, los cuales estaban desorbitados. Por esta acción imprevista, demoré en identificar al sujeto, pues no era nadie más que el esposo de nuestra amada. Yo muy tarde me di cuenta. Él trataba de adentrarse entre empujones y groserías. Procuré salir por el lado opuesto, pero me costaba al igual que al señor bigotudo, pues las bancas estaban repletas de gente. De tanta desesperación por salir, tropecé. En vez de que una señora me ayudara a levantarme, me insultó y me jaloneó de los cabellos. Eso hizo que el esposo estuviese a unos cuantos pasos más sobre mí. De nuevo, intenté huir. Sin embargo, mis nervios me vencieron. Me enredé con la alfombra rojiza de la iglesia, y caí. Luego, solo pude arrastrarme hasta uno de los pasillos que estaba hecho de losetas frías y doradas, con un ligero olor a muerte y una sensación de final tortuoso. El señor se plantó delante de mí, no profirió ni un solo sonido. Me tapaba toda la luz. Me limitaba a permanecer en calma. Se llevó una mano al bolsillo y sacó una pequeña pistola - No me digas nada, basura. Tus acciones ya han hablado mucho por ti. — La gente colindante empezaba a hacer escándalo entre clamores y gritos. Se acercaban en demasía sin entender el altercado. Se agruparon en círculo sobre el monstruo que acababa de sacar un arma. Entonces, con rapidez, supe lo que iba a hacer ese señor. Hizo sonar el gatillo, me disparó por encima del vientre, un tiro certero. iMe disparó!... Quiso hacerlo de nuevo, pero la gente que se escandalizaba lo cogió del brazo y le arrebataron el arma. Ya no pudo hacer nada más. Se fue todo violento hacia la puerta de la salida. Su mujer se le acercaba entre sollozos; por el contrario, él ni siquiera sintió compasión por lo que hizo y lo que haría. No pude escuchar lo que le dijo, pero sí pude ver el potente manazo que le plantó en la mejilla. Vi cómo mi amada caía bruscamente al piso y también pude oír el horrible sonido de esa cobarde cachetada, sonido que se escuchó en toda la iglesia y que perforó el oído de todos los creyentes por el inacabable eco.

¡Muero! iEstoy muriendo! Veo mi propia sangre salir de mi pecho. El color rojo me espanta. Toda mi camisa ya está absolutamente manchada, al igual que mis manos. Trato de respirar un poco más. La falta de oxígeno me traiciona. Pierdo por unos segundos la sensación de seguir viviendo, aunque al instante vomito un gran chorro de sangre que me atrae artificialmente a la tierra. Mi vista se está nublando. "Apártense, apártense, que tome aire. No se acumulen", dice muy tarde uno de los presentes. Me resisto a que me toquen. Vuelvo a sentir esas convulsiones que no puedo detener. Más sangre, más dolor, más sufrimiento y menos vida. Todo se está acaban- 
do. Por la mente, se me cruzan imágenes con rapidez: mi padre, mi madre, mis hermanos, mis faltas, mis alegrías, mis placeres, mis enemigos, mis amigos, mis amadas, mi amada... Todo, todo se vuelve uno. La única persona a la cual quería ver por última vez era a mi amada: Susana. No estaba ahí para amarme. Tal vez sus caricias y su presencia podrían volver a reanimarme, pero... no estaba... iNo estaba! Ahora, en vez de ver mejor, empiezo a distorsionar las figuras humanas: ya no son personas para mí, son monstruos de cuerpos alargados, rechonchos y deformes. Nada tiene sentido. Escucho las voces de las personas, pero a la vez no escucho nada. Mi cuerpo se va poniendo cada vez más rígido, más frío, más tieso... La muerte ya me está Ilamando. Pero... yo me resisto: no quiero morir así, asesinado. ¿Dónde está mi amada? ¿Dónde está? Ya ni puedo ver bien... No puedo. Por más que me esfuerzo, no puedo... Ahora, que mi vista no me engañe, que no lo haga, aunque sea por ser la última vez que la voy a necesitar... Que mi vista no me engañe y me diga si realmente esa mancha roja que se acerca desde lo lejos es mi amada. Veo una mancha deforme con su color de piel. A lo lejos, es ella. Sé que es ella. Está acercándose con velocidad, desesperada. Apenas llego a oír exclusivamente lo que vocifera ella: su voz, la única, es la que escucho ahora, antes de partir. Se acerca más, más rápido, y grita. No distingo sus palabras, pues ya nada me es inteligible. El tiempo me está torturando. No llego a ver a Susana enfrente. Mis ojos se cierran maquinalmente. Ni siquiera puedo resistirme. Mi cuerpo ya no responde a mis órdenes. Me retraigo y me acomodo a ese pesar. Ya no siento nada de mí: solo una pequeña electricidad que recorre todo mi ser, que me provoca la sensación de haberme adormecido. Lanzo el último aire. Trato de no quejarme ante la falta de mi respiración... Pero regresa... Estoy volviendo a sentir que vivo. Ya no puedo abrir los ojos, aunque aún mi corazón late. Siento calor. Este ya no proviene de mí, sino de una segunda persona. Puedo reconocer esos brazos que me están cogiendo, ese lejano olor y esa tierna exhalación. Es mi amada quien me tiene en brazos. "iTe amaba, Luciano, te amaba!", ella dijo estas palabras en tono de maldición. Se adelantó a darme por muerto. En lo sucesivo, me iba a dejar de amar... Así lo dijo. Yo solo asimilé. Y, con estas palabras, mi cuerpo y mi alma expiraron.

\section{Sobre el autor}

Jesús Miguel Delgado Del Aguila es licenciado, candidato a magíster y doctor en Literatura Peruana y Latinoamericana por la Universidad Nacional Mayor de San Marcos. Docente de Educación Superior y universidades nacionales. Corrector de textos. Dos veces becario. Investigador Concytec y Conacyt con intereses en la narrativa, la teoría literaria, el cine y los ensayos de autores latinoamericanos, como Mario Vargas Llosa, Gabriel García Márquez y Octavio Paz. Ha publicado en revistas indexadas en Web of Science, SciELO y Scopus de Perú, Chile, Venezuela, Nicaragua, Brasil, Costa Rica, Puerto Rico, México, Colombia, España e Italia. Ha sido ponente en congresos de Perú, Cuba, España, México, Colombia, Guatemala y Estados Unidos. 